\title{
Broadening the scope of open innovation: past research, current state and future directions
}

\author{
Vareska van de Vrande* \\ Rotterdam School of Management, \\ Erasmus University, \\ P.O. Box 1738, \\ 3000 DR Rotterdam, The Netherlands \\ Fax: +31 104089013 \\ E-mail: vvrande@rsm.nl \\ *Corresponding author
}

\section{Wim Vanhaverbeke}

Department BEW, Hasselt University,

Agoralaan Gebouw D,

3590 Diepenbeek, Belgium

and

Vlerick Leuven Gent Management School,

Vlamingenstraat 83, 3000 Leuven, Belgium

and

ESADE Business School,

Av. Pedralbes 60-62, 08034 Barcelona, Spain

Fax: + 3216623663

E-mail: wim.vanhaverbeke@uhasselt.be

\section{Oliver Gassmann}

Institute of Technology Management,

University of St. Gallen,

Dufourstrasse 40a, CH-9000 St. Gallen, Germany

E-mail: oliver.gassmann@unisg.ch

\begin{abstract}
In this first paper of the special issue, we identify some trends in open innovation research by analysing how the literature on this topics has evolved since the introduction of the concept in 2003. Research on open innovation has been mushrooming ever since and the scope has been broadened in different directions. Researchers also started to analyse open innovation at different level of analysis from the individual actors in organisations to ecosystems and national innovation systems. Despite the vast growth in research on open innovation, we identified several directions for further research: open innovation research should be linked to other management areas such as marketing, HRM, change management, etc. In addition, our understanding of open innovation could be improved if the recently developed insights could be related to the existing management theories.
\end{abstract}

Keywords: open innovation; trends; future directions. 
Reference to this paper should be made as follows: van de Vrande, V., Vanhaverbeke, W. and Gassmann, O. (2010) 'Broadening the scope of open innovation: past research, current state and future directions', Int. J. Technology Management, Vol. 52, Nos. 3/4, pp.221-235.

Biographical notes: Vareska van de Vrande is an Assistant Professor of Strategic Management at the Rotterdam School of Management, Erasmus University (The Netherlands). She is also a Research Fellow at the Ecole Polytechnique Federale de Lausanne (Switzerland). Her research on open innovation focuses on the use of different organisational forms for external technology sourcing, such as corporate venture capital investments, strategic alliances, joint ventures, and mergers and acquisitions. Other research interests include corporate entrepreneurship and corporate venturing. Her work has been published in international journals, such as the Journal of Business Venturing, the Journal of Product Innovation Management, Technovation, R\&D Management, and Creativity and Innovation Management.

Wim Vanhaverbeke is a Professor of Strategy and Innovation at the University of Hasselt (Belgium). He is also a Visiting Professor at ESADE (Spain) and the Vlerick Leuven Gent Management School. He has published in several international journals as Journal of Management Studies, Organization Science, Organization Studies and Journal of Business Venturing and Research Policy. $\mathrm{He}$ is Co-editor with Henry Chesbrough and Joel West of Open Innovation: Researching a New Paradigm. He is extending research about open innovation by setting up Exnovate, an international network of excellence on open and collaborative innovation. He is currently working on a book about 'Managing and organising open innovation'.

Oliver Gassmann is a Professor for Innovation Management at the University of St. Gallen and the Managing Director of the Institute of Technology Management since 2002. Before, he was leading the Corporate Research of the Schindler group as VP Technology Management. Today, he serves as a member in several management boards and academic steering committees. He started his open innovation research in 2002. He has published 12 books and over 200 publications, e.g., Research Policy, Journal of Management, R\&D Management, Management International Review, Journal of World Business, IJTM, IEEE Transactions on Engineering Management. His work has been published in English, German, French, Chinese, and Japanese.

\section{Introduction}

In 2003, Henry Chesbrough coined the term 'open innovation' to describe the phenomenon that in today's landscape of abundant knowledge, companies can no longer afford to rely entirely on their own ideas to advance their business, nor can they restrict their innovations to a single path to market. Although the use of external knowledge and external paths to market as such is not new, Chesbrough (2006) argues that the paradigm of open innovation is different to prior theories of innovation for a number of reasons. Although scholars have noted the existence and importance of external knowledge sources (e.g., Penrose, 1959; Nelson and Winter, 1982; Cohen and Levinthal, 1990; Von Hippel, 1988; Dyer and Singh, 1998), there is an implicit assumption in these works that external knowledge is not more than just an addition to internal innovation, which constitutes the core of firms' innovation performance. The open innovation paradigm, on 
the other hand, explicitly focuses on both internal and external innovation and balances the role of external and internal sources of knowledge.

By doing so, the open innovation paradigm brings together literature streams on different sources of external knowledge, but also calls for a number of changes within firms in order to effectively manage the use of purposive in- and outflows of knowledge. Central in this respect is the increasing importance of the business model for innovation within firms, since it determines which external knowledge is valuable for the firm and should be validated within the company, and which internal knowledge will not create new businesses and should find external paths to market. In addition, an active management of external search (for instance through specialised departments) and external paths to market as well as an active management of intellectual property is crucial to profit in a sustainable way from the benefits of open innovation practices. Hence, open innovation requires a different mindset and the need for a more expanded set of capabilities within companies.

Since the seminal work of Chesbrough (2003), more and more scholars have framed their work under the open innovation umbrella to address the growing need for a comprehensive understanding of the simultaneous use of internal and external innovation. Moreover, a number of dedicated workshops and symposia have been held at well-respected academic conferences such as the Academy of Management (2004, 2005, 2006, 2008), the DRUID Conference (2005), the EURAM Conference 2007, and a specialised Workshop on User and Open Innovation at Harvard Business School in association with MIT (2008). In addition, the $R \& D$ Management journal devoted a special issue to the topic in 2006 and another one was in press at the time of writing. All together, these events and publications have led to the identification of a number of trends in open innovation research.

\section{Trends in open innovation research}

In order to assess the recent trends in open innovation research, we have performed a meta-analysis on a number of articles selected from ISI Web of Knowledge. Selection was based on the following criteria. First, we selected all articles with the topic 'open innovation' that were published between 2004 and 2008. We limited the selection to articles that were related to the subject areas 'management' or 'business', and which were published in leading management journals (see Appendix for an overview of the journals selected). Second, we selected papers that were published in a special issue on 'open innovation'. To our knowledge, $R \& D$ Management (Vol. 36, No. 3) is the first SSCI management journal that published a special issue about open innovation (Gassmann, 2006). Finally, we selected all journal articles that referenced to Chesbrough's 2003 work, and which were published in leading management journals (see Appendix for an overview). After removing duplicates and articles that were deemed not applicable by the authors, the final sample consisted of 88 articles. Of these 88 articles, three were published in 2004, five in 2005, 26 in 2006, 20 in 2007, and 34 in 2008. Figure 1 shows how the number of articles on open innovation has evolved over time.

After the launch of the concept of open innovation, it took about three years before other articles also referred to the phenomenon using the same term, which is most likely related to the time it takes from initial submission to the final publication date. Moreover, even if we do not take into account the publication of a special issue in $R \& D$ 
Management on open innovation in 2006, we observe an upward trend in the number of articles dealing with open innovation as a research topic.

Figure 1 Number of articles on open innovation, 2004-2008

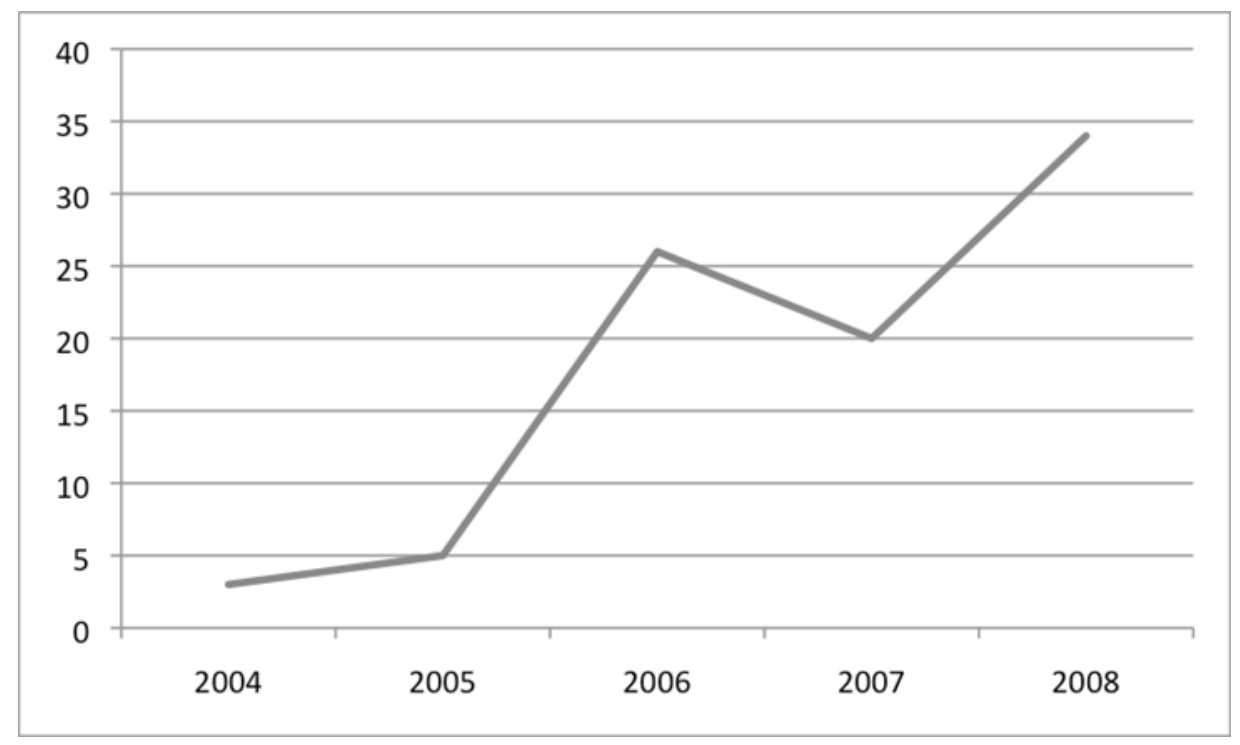

Next, we analysed the final selection of papers in terms of focus, type of research and research setting, and level of analysis.

\subsection{Focus}

Traditionally, open innovation was studied in large, multinational enterprises, most of them operating in technology intensive industries. Chesbrough (2003) defines the concept using qualitative findings from case studies of large, technology savvy firms and he focuses primarily on the inside-out side of open innovation. Currently, open innovation literature takes a much broader perspective on the topic. Although the focus is still very much on practices of large MNEs, there are a few articles that look specifically at open innovation in SMEs (e.g., De Jong and Marsili, 2006; Massa and Testa, 2008). Also, despite the interest for the inside-out facet of open innovation, some authors have also picked up the challenges in firms associated with the outside-in aspect, i.e., acquiring new knowledge from outside the firm (e.g., Lichtenthaler and Ernst, 2007; Van de Vrande et al., 2006; Witzeman et al., 2006). Technology transactions, in both directions, remain an important field of study for open innovation scholars. In addition, there has been growing attention to the use of corporate venture capital and university-collaboration to get access to new, early stage technologies (Allen and Hevert, 2007; Gaba and Meyer, 2008; Markham et al., 2005; Becker and Gassmann, 2006; Waites and Dies, 2006). Moreover, user innovation, customer interaction and alliance networks have recently received a fair share of attention in the open innovation literature (Hienerth, 2006; Lettl, 2007; Lettl et al., 2006; Piller and Walcher, 2006; Gassmann and Zeschky, 2008; Van Rijswijk et al., 2008). In addition, a topic that can be seen as one of the foundations of the open innovation principles is the development of open source 
software (OSS). This remains a very popular topic in the open innovation debate and many authors use the principles of OSS development as a basis for our understanding of open innovation management (e.g., Gruber and Henkel, 2006; Henkel, 2006; Pykäläinen, 2007; West and Gallagher, 2006).

\subsection{Type of research}

What type of research do we find in the 88 open innovation related papers that have been published over the past five years? Thirty-three out of 88 papers had a theoretical scope, sometimes using case material as an illustration (see Figure 2).

Figure 2 Type of research

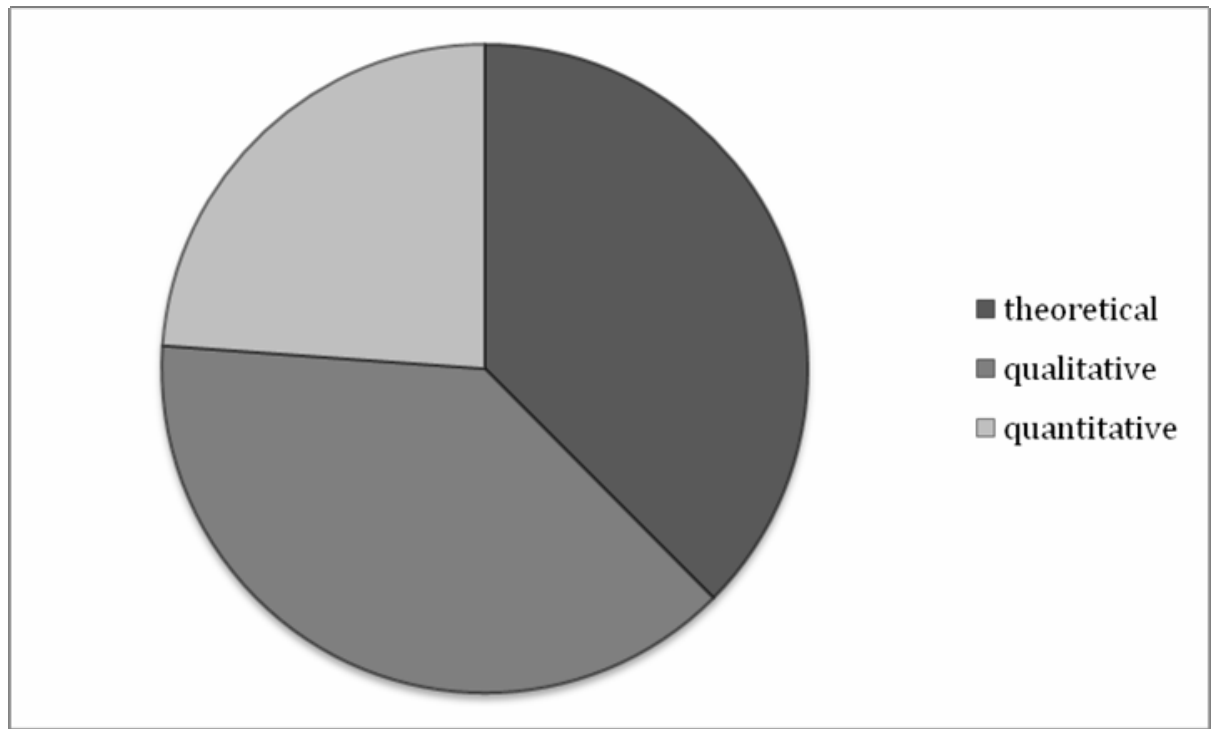

Of the remaining 55 papers that had an empirical focus, 34 had a qualitative approach (using a small sample of case studies) and 21 papers were using quantitative data, based on large-scale datasets, which often comprised several industries. As for the industry breakdown of past publications, hardly any of the single-industry papers moves beyond the traditional focus on technology intensive industries. Although high-tech firms prove to be an interesting field of study, the applicability of the underlying principles of open innovation is certainly not limited to technology intensive industries but can very well be extended to low-tech industries. In this respect, it is interesting to mention articles focusing on the sports industry and the gaming industry (e.g., Hienerth, 2006; Lecocq and Demil, 2006; Piller and Walcher, 2006; Prügl and Schreier, 2006), which are not typical high-tech industries.

Sample-size also varies significantly between the different papers: about one third of the qualitative papers uses a single case study to derive the results, and another one third of this group limits the size of the dataset to less than ten case studies. As for the quantitative analyses, about $50 \%$ of the papers use a sample size between 100 and 300 firms, whereas some exceptional large datasets comprise over 1,000 firms. It is striking that to our knowledge, only two of the empirical papers in our dataset collected data 
outside of Europe and/or the USA. Although we could not trace this information for about one third of the empirical papers in our dataset, this indicates that some regions, such as Asia, are currently underrepresented in open innovation studies.

\subsection{Level of analysis}

Although open innovation was originally introduced as a firm level concept, West et al. (2006) argue that in order to strengthen research about open innovation, other levels of analysis have to be taken into account as well. Over the past five years, still more than $50 \%$ of the empirical papers in our sample take the firm as unit of analysis. Other levels of analysis include a focus on individuals $(11 \%)$, dyads $(5 \%)$, innovation projects $(15 \%)$, clusters in geographically bounded regions (7\%) and industry level analysis (7\%).

We can thus conclude that open innovation research has diverged over the past five years: Instead of focusing on large MNEs in technology intensive industries in the USA, research has expanded into finer-grained topics, such as the role of individuals and project-level use of open innovation practices in MNEs as well as SMEs. The methodology is moving away from case studies to the complementary use of large-scale, multiple industry datasets. However, there is still ample room for improvement, such as the geographical scope of empirical studies and reintegration of other aspects of open innovation into the broader framework of using inside and outside sources of knowledge simultaneously while developing new technologies. The next section will explain in more detail how this special issue contributes to an increased understanding of the role of open innovation and the management thereof.

\section{Broadening the scope of open innovation in this special issue}

The term open innovation was coined only six years ago and open innovation research is still in its infancy. With this special issue, we try to broaden the scope of open innovation. It comprises 12 articles that advance our understanding of open innovation in different ways. First, there is a broader range of research topics related to open innovation: open innovation in SMEs, open innovation and competition patterns, the role of individuals in open innovation, the relationship between open innovation and entrepreneurship in determining the innovation performance, and how firms can profit from large-scale from of open innovation, just to mention a few ones. Second, the geographical and industry scope has expanded; open innovation is practiced in many industries and around the globe. Responding to the need for empirical studies outside of Europe and the US, the special issue includes two articles about open innovation in Korea and Taiwan indicating that open innovation is also gaining a foothold in Asian economies. Third, empirical evidence on open innovation is based on diverse data sources. Some papers use archival data but most are based on surveys. These allow researchers to bring in the role of individuals in open innovation and to introduce a wealth of data about motives, incentives, barriers and attitudes in the empirical analysis.

Most previous open innovation studies have analysed open innovation practices in large manufacturing enterprises. Open innovation in SMEs is a relatively uncharted research area (an exception is Van de Vrande et al., 2009) and, therefore, we are keen to introduce studies about SMEs in this special issue. The study of Kim and Park discusses the effects of open innovation practices in Korean SMEs. Based on a quantitative 
database of 1,348 Korean firms - 1,140 SMEs and 244 large companies - they analyse the effect of three different external innovation activities - external idea sourcing, external knowledge sourcing and external R\&D - on innovative performance of large firms and SMEs. They find that external innovation activities have a different effect on the two types of firms. External R\&D improves the innovation performance of both but the innovation performance of SMEs is not affected by external knowledge sourcing and is negatively affected by external idea sourcing. In contrast to larger firms that are more successful in detecting and integrating externally developed technology, external idea and knowledge sourcing innovation activities do not improve the innovation performance of SMEs. These results imply that the lessons learned from open innovation in large firms are not readily transferable to the context of SMEs making the need for specific studies on open innovation in SMEs even more urgent.

Other studies in this special issue link open innovation to research fields that were until now unconnected. Hung and Chiang use data from 122 Taiwanese electronic product manufacturers to focus on the question of firms' proclivity towards the use of open innovation. They find that open innovation proclivity and entrepreneurial orientation positively affect firm performance. Moreover, their findings point towards the fact that entrepreneurial orientation and open innovation reinforce each other, suggesting that an entrepreneurial orientation can help managers to benefit more effectively from the open innovation activities.

Jaspers and Van den Ende discuss the use of open innovation in the development of complex products. They argue that the context of complex products makes it very difficult for firms to internally develop all components and subsystems. As a result, open innovation is almost a requirement for firms to be competitive in these industries. They point out how systems integration and open innovation are complements in the development of complex products, arguing that the effective coordination of component innovation requires the application of different open innovation mechanisms.

Another interesting but relatively uncharted research topics is how open innovation relates to patterns of competition in different industries. Lim, Chesbrough and Ruan examine patterns of R\&D competition in the semiconductor industry. Focusing on the research strategy of three important players in this industry (IBM, Intel, and AMD), they show how the patterns of cooperation and competition change over time between these firms. The results of this study indicate that models of strategic choice should expand beyond 'compete or collaborate' to consider alternative modes of co-opetition. The coopetition we observe among IBM, Intel and AMD involves a highly asymmetric pattern with Intel and AMD depending heavily on IBM for knowledge, but not vice-versa. Moreover, the authors find that knowledge sources for the three firms are far more diffuse than that possessed by the leading semiconductor firms resulting in an abundance of knowledge distributed across a large number of participants. In such instances, upstream technology development is only loosely coupled to downstream product market competition, consistent with the open innovation model.

Several contributions to this issue have connected open innovation activities of firms to their internal assets, organisation, or culture. The article by Herzog and Leker distinguishes different innovation cultures that are needed for closed and open innovation. By doing so, this paper sheds light on the cultural dimensions of implementing open innovation in firms. Based on data collected in three innovation units of a single chemical firm, they find that the open innovation unit studied here is less 
infected with the 'not invented here' syndrome and is more open towards risk-taking. This study shows how firms have to change their innovation culture to become successful in open innovation. More empirical research is needed on strategy, organisational culture and structure, and human factors in order to effectively execute open innovation.

Next, the paper by Enkel focuses on the open innovation networks, particularly on the attributes needed by individual network members to benefit from the cooperation. Using data from the European network for research on radiation dosimetry (EURADOS), the findings point towards the importance of individual prerequisites such as openness and the possibility to contribute on the organisational level as requirements for profiting from open innovation networks. In short, not only the organisational characteristics of the network members but also the attributes of the individuals in these organisations help to explain when and why firms profit from a more open approach to open innovation networks.

In a similar vein, Lichtenthaler links open innovation activities to the internal assets of the firms. More specifically, he analyses how the size and quality of firms' patent portfolios have an impact on its external technology acquisition on the one hand and external technology commercialisation on the other hand. Based on a survey of 154 firms in Germany, Austria and Switzerland, the author finds that patent portfolio size and quality are negatively related to external technology acquisition (outside-in), whereas patent portfolio quality is positively related to external technology exploitation (inside-out). As a result, the existing IP portfolio of firms appears to be an important driver of open innovation. Understanding the causal relationships between internal technological capabilities and open innovation activities is a very interesting avenue to deepen and broaden our understanding of open innovation.

Neyens, Sels and Faems investigate the benefits of using different types of alliance strategies for startup firms. In particular, collaboration with suppliers, customers and competitors is associated with incremental innovation performance (e.g., ability to improve existing products/technologies), while collaboration with universities, research institutes and again competitors is positively linked to radical innovation performance (e.g., ability to create new products/technologies). Using longitudinal data on 217 Flemish startup firms, they find that discontinuous alliances are related to incremental innovation performance, whereas continuous alliance strategies were associated with a higher explorative innovation performance. Their findings suggest that startup firms should this study encourages startup firms to balance their alliance portfolio not only in terms of different kinds of partners but also in terms of different kinds of time frames, pursuing different open innovation strategies at the same time, focusing on both short-term and long-term collaboration efforts with different types of partners.

OSS and other user communities have recently been described extensively. Most attention has been paid to the growth and dynamics of these communities, the reasons why individuals contribute, and how the performance of these open designs compare to proprietary designs. In comparison, much less attention has been paid to the role of firms in the community and how they can profit from their participation. Because of this lack of attention for companies in open communities, the link between open innovation and user community has been loose so far. Therefore, we welcomed several studies in this special issue that tighten the link between both. The first paper, authored by Spaeth, Stuermer and Krogh investigate the existence of the so-called 'push model' of open innovation, in which firms do not just use readily available external knowledge, but also stimulate outsiders to voluntarily create new knowledge which can be used in the innovation 
process. To illustrate their model, they use an extensive case study of the Eclipse platform, an integrated development environment. The study analyses in detail how large companies can benefit from technology platforms. The study illustrates how important it is for a firm to successfully manage a technology platform. Based on their findings, the authors propose that a push model of open innovation is enabled through preemptive generosity, continuous commitment, adaptive governance structures and lowering barriers to entry.

Next, Perr, Appleyard and Sullivan examine the different business models that have emerged in OSS, providing an insight as to how companies involved in OSS can capture the value associated with their products and services. Based on evidence collected through more than 20 interviews with OSS executives, they find that three factors play a primary role in the adoption of a particular business model: IP ownership, management of the community, and selection of market segments and product categories. Based on these three factors, seven different business models are defined that are used by these firms.

Müller-Seitz and Reger discuss the application of OSS development principles on the development of a low-tech, intangible product: Wikipedia. Despite the differences between Wikipedia and traditional OSS projects, the authors find that various insights from OSS are also applicable to Wikipedia. In addition, the findings reveal a number of counter-intuitive elements that point towards the limitations and other issues associated with open innovation and OSS-inspired projects.

Finally, Rayna and Striukova offer a detailed comparison between two large-scale forms of open innovation: open source and patent pools. Although both have the advantage of providing access to a large number of potential sources of innovation while lowering $\mathrm{R} \& \mathrm{D}$ expenditures and transaction costs, they differ in their nature of cooperation, appropriability, feasibility, and requirements for participation. In our opinion, this study broadens our view on large-scale forms of open innovation: scholars should explore what different types of large-scale forms of open innovation are available and under which conditions or for which purpose they can be used effectively. It is a fruitful way to broaden our view on large-scale systems of open innovation and contrast them with open innovation where only one or a few partners our included.

\section{Some directions for future research on open and collaborative innovation}

The objective of this special issue is to broaden the scope of research about open innovation. However, we are aware of the fact that this is only a minor step on the road to gaining a better understanding of the sources, benefits, and drivers of open innovation. In our opinion, there are still many uncharted research domains. We thus enumerate a number of them without having the ambition to be exhaustive.

There is an ongoing debate about the novelty of open innovation. However, it seems that this debate is based on a misconception because most scholars agree that openness in R\&D is not a new phenomenon. EIRAM (2005) concluded that in- and outsourcing of $R \& D$ is not a new phenomenon and that the situation following the Second World War, when the greatest proportion of $R \& D$ was carried out in-house, was in fact an unusual situation. Chesbrough (2006) described how open innovation follows a long tradition of studying the processes of innovation. Business historians have documented that 
innovation was a rather open system with extensive markets for innovation that predated the rise of the corporate R\&D laboratory in the middle of the 20th century (Lamoreaux and Sokoloff, 1999; Lerner, 2000). Mowery (2009) recently discussed trends before and after 1985 in the structure of US industrial R\&D and came to a similar conclusion that many elements of the open innovation approach to $R \& D$ were already present in large firms' in-house R\&D in the 20th century. We encourage scholars to redirect the antithetical closed versus open innovation debate towards a more promising research approach by explaining how open innovation strategies enable firms to create a competitive advantage in unprecedented ways and how an open innovation approach requires a different organisational structure and mindset than the more traditional R\&D approaches do.

Next, we think that there is an urgent need to integrate open innovation in the existing literature about external technology acquisition and cooperation. Since open innovation is, to a large extent, derived from managerial practice, it provides an integrative approach to innovation management combining corporate and business strategy, business modelling, collaborative agreements with innovation partners, IP-policy, etc., into an inextricable hairball. Conversely, this practice-based approach has the disadvantage in that thus far open innovation has only been loosely connected to the existing innovation management literature and the underlying management theories. Decomposing Chesbrough's (2006) open innovation model results in at least four constituent dimensions; value creation and value capturing via the business model of the innovating firm, transactions/alliances with its innovation partners, (dynamic) capabilities or competencies, and technological and market uncertainties which are embedded in the funnel concept. These dimensions suggest that different management theories should be combined to improve our understanding of open innovation from a scholarly point of view. More specifically, the four dimensions mentioned above suggest that scholars have to explore combinations between the following literature streams; value creation and sharing in cooperative settings (Brandenburger and Nalebuff, 1996), transaction cost and transaction value theory (Williamson, 1975, 1985; Zajac and Olsen, 1993), the resource (knowledge) based view (Wernerfelt, 1984; Barney, 1986, 1991; Grant and Baden-Fuller, 2004), the dynamic capabilities approach (Teece et al., 1997; Teece, 2007; Eisenhardt and Martin, 2000); the relational view (Dyer and Singh, 1998; Dyer, 1997), the organisational learning theory (March and Olsen, 1975; Levinthal and March, 1993) and the real options theory (Folta, 1998; Folta and Miller, 2002).

Finally, we are convinced that future research has to continue to broaden the scope of open innovation research to exploit its full potential. West et al. (2006) have already pointed to the necessity to extend research about open innovation to different levels of analysis; what is the impact of open innovation on knowledge workers and managers in a company that decides to open up its innovation process? How should technology in- and out-sourcing be organised and managed in order to guarantee smooth interorganisational technology transfers? What is the role of innovation projects in establishing open innovation in a firm? What is at the corporate level, the link between open innovation, corporate strategy, and organisational renewal? What is the impact of open innovation on core competencies of large firms (Christensen, 2006)? How to analyse open innovation at the level of industrial systems (Christensen et al., 2005) or from the perspective of regional innovation systems? What are public policy implications of open innovation (De Jong et al., 2008; OECD, 2008)? 
We also support initiatives that aim to couple open innovation to other disciplines or management areas. Absorptive capacity (Cohen and Levinthal, 1990; Zahra and George, 2002; Todorova and Durisin, 2007) is obviously a concept with a strong potential to connect to the insights related to open innovation. Moreover, the original application fields of open innovation are closely linked to external corporate venturing in large manufacturers. Open innovation is applicable to many more settings. Technology is only one source of innovation; design, market intelligence, crowd sourcing, design and creativity are only a few examples where open innovation can be applied successfully. Furthermore, there are also ample research opportunities to link open innovation to HRM and marketing since open innovation typically produces serious HRM-problems and offers opportunities in co-branding and co-distribution. Additionally, large firms are, in most cases, multinationals that are not only paying attention to co-innovation with external partners, but are also interested in setting up a globalised R\&D network with specialised partners in different locations (Doz et al., 2001, 2006). This implies that open innovation and globalisation of R\&D cannot be disentangled from each other. Finally, open innovation research should focus more on SMEs: current research is still very limited (Van de Vrande et al., 2009; De Jong and Marsili, 2006; Massa and Testa, 2008) and is not yet revealing the creative use of open innovation by many SMEs around the globe to successfully create new products or businesses. Even SMEs in low-tech industries have proven to be very successful in using and integrating knowledge from external partners, which are frequently based in unrelated industries, to create new products or services. It is interesting to observe that the drivers and mechanisms underlying open innovation in this setting cannot be derived from the context of large firms' external corporate venturing activities to which open innovation has been applied originally.

\section{Acknowledgements}

The editors would like to thank the Editor-in-Chief Mohamed Dorgham for providing the opportunity to publish a special issue in the International Journal of Technology Management. In addition, the authors wish to thank the reviewers whose careful examination of the submitted papers has helped in selecting high quality papers and in shaping this special issue. In particular, we would like to thank the following external reviewers:

\begin{tabular}{lll}
\hline Ard-Pieter de Man & Jens Froslev Christensen & Oana Branzei \\
Christian Le Bas & Jeroen de Jong & Raymond van Wijk \\
Christoph Hienerth & Keld Laursen & Reinhard Prügl \\
Christopher Lettl & Koen Dittrich & Remko van der Lugt \\
David Gann & Kwanghui Lim & Sonali Shah \\
Ellen Enkel & Linus Dahlander & Thomas Keil \\
Felipe Monteiro & Markku Maula & Wendy van der Valk \\
Frank Piller & Marko Torkkeli & Wilfred Schoenmakers \\
Geert Duysters & Martin Schreier & Zi-Lin He \\
Hans Bruining & Myriam Cloodt & \\
\hline
\end{tabular}




\section{References}

Allen, S.A. and Hevert, K.T. (2007) 'Venture capital investing by information technology companies: did it pay?', Journal of Business Venturing, Vol. 22, pp.262-282.

Arora, A., Fosfuri, A. and Gambardella, A. (2001) Markets for Technology, The MIT Press, Cambridge, MA.

Barney, J.B. (1986) 'Strategic factor markets: expectations, luck, and business strategy', Management Science, Vol. 21, pp.1231-1241.

Barney, J.B. (1991) 'Firm resources and sustained competitive advantage', Journal of Management, Vol. 17, pp.99-120.

Becker, B. and Gassmann, O. (2006) 'Gaining leverage effects from knowledge modes with corporate incubators', $R \& D$ Management, Vol. 36, pp.1-16.

Brandenburger, A.M. and Nalebuff, B.J. (1996) Co-opetition, Harvard Business School Press, Boston, MA.

Chesbrough, H. (2003) Open Innovation: The New imperative for Creating and Profiting from Technology, Harvard Business School Press.

Chesbrough, H.W. (2006) 'Open innovation: a new paradigm for understanding industrial innovation', in Chesbrough, H.W., Vanhaverbeke, W. and West, J. (Eds.): Open Innovation: Researching a New Paradigm, Oxford University Press, Oxford.

Christensen, J-F., Olesen, M.H. and Kjær, J.S. (2005) 'The industrial dynamics of open innovation - evidence from the transformation of consumer electronics', Research Policy, Vol. 34, pp.1533-1549.

Christensen, J-F. (2006) 'Wither core competency for the large corporation in an open innovation world?', in Chesbrough, H.W., Vanhaverbeke, W. and West, J. (Eds.): Open Innovation: Researching a New Paradigm, Oxford University Press, Oxford.

Cohen, W.M. and Levinthal, D.A. (1990) 'Absorptive capacity: a new perspective on learning and innovation', Administrative Science Quarterly, Vol. 35, pp.128-152.

De Jong, J.P.J. and Marsili, O. (2006) 'The fruit flies of innovations: a taxonomy of innovative small firms', Research Policy, Vol. 35, No. 2, pp.213-229.

De Jong, J.P.J., Vanhaverbeke, W., Kalvet, T. and Chesbrough, H. (2008) Policies For Open Innovation: Theory, Framework and Cases, Research project funded by VISION-Eranet, Helsinki.

Doz, Y., Santos, J. and Williamson, P. (2001) From Global to Metanational: How Companies Win in the Knowledge Economy, Harvard Business School Press, Boston MA.

Doz, Y., Wilson, K., Veldhoen, S., Goldbrunner, T. and Altman, G. (2006) Innovation: Is Global the Way Forward?, INSEAD, Fontainbleau, France.

Dyer, J.H. (1997) 'Effective interfirm collaboration: how firms minimize transaction costs and maximize transaction value', Strategic Management Journal, Vol. 18, No. 7, pp.535-556.

Dyer, J.H. and Singh, H. (1998) 'The relational view: cooperative strategy and sources of interorganizational competitive advantage', Academy of Management Review, Vol. 23, No. 4, pp.660-679.

EIRMA (2005) Technology Access for Open Innovation, WG63 Report, 36p.

Eisenhardt, K.M. and Martin, J.A. (2000) 'Dynamic capabilities: what they are?', Strategic Management Journal, Vol. 21, pp.1105-1121.

Folta, T.B. (1998) 'Governance and uncertainty: the trade-off between administrative control and commitment', Strategic Management Journal, Vol. 19, pp.1007-1028.

Folta, T.B. and Miller, K.D. (2002) 'Real options in equity partnerships', Strategic Management Journal, Vol. 23, pp.77-88.

Gaba, V. and Meyer, A.D. (2008) 'Crossing the organizational species barrier: how venture capital practices infiltrated the information technology sector', Academy of Management Journal, Vol. 51, pp.976-99. 
Gassmann, O. (2006) 'Opening up the innovation process: towards an agenda', $R \& D$ Management, Vol. 36, pp.223-226.

Gassmann, O. and Zeschky, M. (2008) 'Opening up the solution space: the role of analogical thinking for breakthrough product innovation', Creativity and Innovation Management, Vol. 17, pp.97-106.

Grant, R.M. and Baden-Fuller, Ch. (2004) 'A knowledge accessing theory of strategic alliances', Journal of Management Studies, Vol. 41, No. 1, pp.61-84.

Gruber, M. and Henkel, J. (2006) 'New ventures based on open innovation - an empirical analysis of start-up firms in embedded Linux', International Journal of Technology Management, Vol. 33, pp.356-372.

Henkel, J. (2006) 'Selective revealing in open innovation processes: the case of embedded Linux', Research Policy, Vol. 35, pp.953-969.

Hienerth, C. (2006) 'The commercialization of user innovations: the development of the rodeo kayak industry', $R \& D$ Management, Vol. 36, pp.273-294.

Lamoreaux, N. and Sokoloff, K. (1999) 'Inventive activity and the market for technology in the United States, 1840-1920', National Bureau of Economic Research, Working Paper No. 7107.

Lecocq, X. and Demil, B. (2006) 'Strategizing industry structure: the case of open systems in low-tech industry', Strategic Management Journal, Vol. 27, pp.891-898.

Lerner, J. (2000) ' 150 years of patent office practice', National Bureau of Economic Research, Working Paper No. 7477.

Lettl, C. (2007) 'User involvement competence for radical innovation', Journal of Engineering and Technology Management, Vol. 24, Nos. 1-2, pp.53-75.

Lettl, C., Herstatt, C. and Gemuenden, H.G. (2006) 'Users' contributions to radical innovation: evidence from four cases in the field of medical equipment technology', $R \& D$ Management, Vol. 36, pp.251-272.

Levinthal, D.A. and March, J.G. (1993) 'The myopia of learning', Strategic Management Journal, Vol. 14, pp.94-112.

Lichtenthaler, U. and Ernst, H. (2007) 'External technology commercialization in large firms: results of a quantitative benchmarking study', $R \& D$ Management, Vol. 37, pp.383-397.

March, J.G. and Olsen, J.P. (1975) 'The uncertainty of the past: organizational learning under ambiguity', European Journal of Political Research, Vol. 3, pp.147-171.

Markham, S., Gentry, S.T., Hume, D., Ramachandran, R. and Kingon, A.I. (2005) 'Strategies and tactics for external corporate venturing', Research-Technology Management, Vol. 48, No. 2, pp.49-59.

Massa, S. and Testa, S. (2008) 'Innovation and SMEs: misaligned perspectives and goals among entrepreneurs, academics, and policy makers', Technovation, Vol. 28, pp.393-407.

Mowery, D.C. (2009) 'Plus ca change: industrial R\&D in the "third industrial revolution", Industrial and Corporate Change, Vol. 18, No. 1, pp.1-50.

Nelson, R. and Winter, S. (1982) An Evolutionary Theory of Economic Change, Harvard University Press, Cambridge, MA.

OECD (2008) Globalization and Open Innovation, OECD, Paris.

Penrose, E.T. (1959) The Theory of the Growth of the Firm, Blackwell, Oxford.

Piller, F.T. and Walcher, D. (2006) 'Toolkits for idea competitions: a novel method to integrate users in new product development', R\&D Management, June, Vol. 36, No. 3, pp.307-318.

Prügl, R. and Schreier, M. (2006) 'Learning from leading-edge customers at The Sims: opening up the innovation process using toolkits', R\&D Management, Vol. 36, pp.237-250.

Pykäläinen, T. (2007) 'Model for profiting from software innovations in the new era in computing', Technovation, Vol. 27, pp.179-193.

Teece, D.J., Pisano, G. and Shuen, A. (1997) 'Dynamic capabilities and strategic management', Strategic management Journal, Vol. 18, pp.509-534. 
Teece, D.J. (2007) 'Explicitating dynamic capabilities: the nature and microfoundations of (sustainable) enterprise performance', Strategic Management Journal, Vol. 28, pp.1319-1350.

Todorova, G. and Durisin, B. (2007) 'Absorptive capacity: valuing a reconceptualization', Academy of Management Review, Vol. 32, No. 3, pp.774-786.

Van de Vrande, V., Lemmens, C. and Vanhaverbeke, W. (2006) 'Choosing governance modes for external technology sourcing', $R \& D$ Management, Vol. 36, pp.347-363.

Van de Vrande, V., De Jong, J., Vanhaverbeke, W. and De Rochemont, M. (2009) 'Open innovation in SMEs: trends, motives and management challenges', Technovation, forthcoming.

Van Rijswijk, M., Kleijn, M., Janson, M. and Menten, E. (2008) 'The process and experiences with creating user-driven innovation programmes in the Netherlands', Technology Analysis \& Strategic Management, Vol. 20, pp.309-320.

Von Hippel, E. (1988) The Sources of Innovation, Oxford University Press, New York.

Waites, R. and Dies, G. (2006) 'Corporate research and venture capital can learn from each other', Research-Technology Management, Vol. 49, No. 2, pp.20-24.

Wernerfelt, B. (1984) 'A resource based view of the firm', Strategic Management Journal, Vol. 5, pp.171-180.

West, J. and Gallagher, S. (2006) 'Challenges of open innovation: the paradox of firm investment in open-source software', $R \& D$ Management, Vol. 36, pp.319-331.

West, J., Vanhaverbeke, W. and Chesbrough, H.W. (2006) 'Open innovation: a research agenda', in Chesbrough, H.W., Vanhaverbeke, W. and West, J. (Eds.): Open Innovation: Researching a New Paradigm, Oxford University Press, Oxford.

Williamson, O.E. (1975) Markets and Hierarchies: Analysis and Antitrust Implications, Study in the Economics of Internal Organization, Free Press, New York.

Williamson, O.E. (1985) The Economic Institutions of Capitalism: Firms, Markets, Relational Contracting, Free Press, New York.

Witzeman, S., Slowinski, G., Dirkx, R., Gollob, L., Tao, J., Ward, S. and Miraglia, S. (2006) 'Harnessing external technology for innovation', Research Technology Management, Vol. 49, No. 3, pp.19-27.

Zajac, E.J. and Olsen, C.P. (1993) 'From transaction cost to transactional value analysis: implications for the study of interorganizational strategies', Journal of Management Studies, Vol. 30, pp.131-145.

Zahra, S.A. and George, G. (2002) 'Absorptive capacity: a review, reconceptualization and extension', Academy of Management Review, Vol. 27, pp.185-203. 


\section{Appendix}

Journal having published open innovation articles 2004-2008

\begin{tabular}{lc}
\hline Journal & Number of articles in dataset \\
\hline R\&D Management & 15 \\
Research-Technology Management & 14 \\
International Journal of Technology Management & 13 \\
Research Policy & 8 \\
California Management Review & 5 \\
Technovation & 5 \\
Journal of Engineering and Technology Management & 3 \\
Journal of Management Studies & 3 \\
Journal of Product and Innovation Management & 3 \\
Technology Analysis \& Strategic Management & 3 \\
IEEE Transactions on Engineering Management & 2 \\
Journal of Business Venturing & 2 \\
Long Range Planning & 2 \\
Management Decision & 2 \\
Organization Science & 2 \\
Academy of Management Journal & 1 \\
Entrepreneurship Theory and Practice & 1 \\
Management Science & 1 \\
MIT Sloan Management Review & 1 \\
Organization Studies & 1 \\
Strategic Management Journal & 1 \\
\hline
\end{tabular}

